\title{
Physiological response of Polygonum perfoliatum L. following exposure to elevated manganese concentrations
}

by Xue, S., Wang, J., Wu, C., Li, S., Hartley, W., Wu, H. Zhu, H., Zhu, F. and Cui, M.

Copyright, Publisher and Additional Information: This is the author accepted manuscript. The final published version (version of record) is available online via Springer

Please refer to any applicable terms of use of the publisher.

DOI: https://dx.doi.org/10.1007/s11356-016-8312-7

Harper Adams

University

Xue, S., Wang, J., Wu, C., Li, S., Hartley, W., Wu, H. Zhu, H., Zhu, F. and Cui, M. 2016. Physiological response of Polygonum perfoliatum $L$. following exposure to elevated manganese concentrations. Environmental Science and Pollution Research.

29 December 2016 
1 Physiological response of Polygonum perfoliatum L. following exposure to elevated manganese concentrations

3 Shengguo Xue ${ }^{1 *}$, Jun Wang ${ }^{1}$, Chuan $\mathrm{Wu}^{1}$, Song $\mathrm{Li}^{2 *}$,William Hartley ${ }^{3}$, Hao $\mathrm{Wu}^{1}$, Feng Zhu ${ }^{1}$, Mengqian Cui ${ }^{1}$

$4 \quad{ }^{1}$ School of Metallurgy and Environment, Central South University, Changsha 410083, P.R. China

$5 \quad{ }^{2}$ Institute of Ecology and Rural Environment Planning, Chinese Academy for Environmental Planning, P.R.

6 China

$7{ }^{3}$ Crop and Environment Sciences Department, Harper Adams University, Newport, Shropshire, TF10 8NB,

8 United Kingdom

$9 *$ Corresponding authors:

10 Tel: + 86 13787148441, E-mail: sgxue70@ hotmail.com; sgxue@ @su.edu.cn (Prof. Shengguo Xue);

11 Tel: +86 18610490925, E-mail: lisong@ @aep.org.cn (Dr. Song Li) 


\section{Abstract:}

Polygonum perfoliatum L. is a Mn-tolerant plant having the potential to grow in mine wasteland with elevated manganese concentrations. The physiological changes of $P$. perfoliatum grown in different Mn concentrations (5, $500,1000,2000,5000,10000 \mu \mathrm{mol} \cdot \mathrm{L}^{-1}$ ) were investigated in glasshouse study to evaluate its tolerance and physiological response to accumulated manganese. A hydroponic study was carried out in order to study the changes in ultrastructure with increasing Mn concentrations $\left(5,1000\right.$, and $\left.10000 \mu \mathrm{mol} \cdot \mathrm{L}^{-1}\right)$. Absorption bands of P. perfoliatum differed greatly in lipids, proteins and carbohydrates. With elevated levels of $\mathrm{Mn}\left(5-2000 \mu \mathrm{mol} \cdot \mathrm{L}^{-}\right.$

$\left.{ }^{1}\right)$, absorbance changed little, which demonstrated that lower Mn concentrations had a negligible influence on transport functions. With Mn concentrations in excess of $2000 \mu \mathrm{mol} \cdot \mathrm{L}^{-1}$, absorbance increased slightly but then eventually decreased. Lower Mn concentrations (5 and $\left.1000 \mu \mathrm{mol} \cdot \mathrm{L}^{-1}\right)$ had no breakage function to the ultrastructure of $P$. perfoliatum. However, as Mn concentration increased to $10000 \mu \mathrm{mol} \cdot \mathrm{L}^{-1}$, visible damage became evident, the quantity of mitochondria in root cells increased and the grana lamellae of leaf cell chloroplasts revealed a disordered state. Compared with controls, black agglomerations were observed in cells of P. perfoliatum grown with 1000 and $10000 \mu \mathrm{mol} \cdot \mathrm{L}^{-1} \mathrm{Mn}$ for 30 days. As the Mn concentration reached 10000 $\mu \mathrm{mol} \cdot \mathrm{L}^{-1}$, a novel acicular substance developed in leaf cells and intercellular spaces, possibly indicating a tolerance mechanism in $P$. perfoliatum. These results confirm that $P$. perfoliatum shows potential for the revegetation of abandoned Mn tailings.

Key words: Polygonum perfoliatum L.; Manganese tolerance; Chemical composition; Ultrastructure 


\section{Introduction}

Large areas of metalliferous ore from mining and smelting contain highly toxic metal concentrations, e.g. lead, zinc and manganese, which are phytotoxic to many plant species, and therefore restrict vegetation establishment (Wu et al. 2016; Kong et al. 2017). Plants that have evolved to colonize heavy metal contaminated soils may be classified into two basic strategies, exclusion mechanisms and accumulation (Baker et al. 1989). Metal hyperaccumulating plants are less susceptible to the toxicity of heavy metals, and demonstrate tolerance which has become valuable for phytoremediation of contaminated soils (Hao et al. 2013; Wu et al.2017). It has been reported that more than 500 hyperaccumulators have been discovered, but less than 30 are applicable to manganese (Mn) tolerance (Fernando et al. 2013).

Generally, heavy metals with high concentration would induce damage of cellular ultrastructures in plants; such damage is mainly towards alterations of cellular organelles, e.g. chloroplast, mitochondria and vacuole (Weng et al. 2013; Liu et al. 2017; Chen et al. 2017). Additionally, the extent of damage was closely related to exposure time and concentration of the heavy metal (Keller et al. 2015). For example, the ultrastructure of Sargassum pallidum cells were irregular and abnormal following exposure to excessive concentrations of $\mathrm{Cu}, \mathrm{As}$, and $\mathrm{Pb}$, whereas $\mathrm{Cd}$ particularly destroyed the ultrastructure of chloroplasts and inhibited Chl synthesis (Miao et al. 2014). Elevated $\mathrm{Pb}$ concentrations have been shown to adversely affect the cellular structure of Caenotus canadensis $\mathrm{L}$. roots ( $\mathrm{Li}$ et al. 2016) whilst $\mathrm{Zn}$ is sequestered in metallo-organic compounds located in leaf vacuoles of Thlaspi caerulescens to prevent $\mathrm{Zn}$ toxicity (Kupper et al. 1999). Physiological parameters of damage include decreased chlorophyll a production indicating less photosynthetic efficiency, an increase in lipid peroxidation and electrolyte conductivity indicating cell membrane injuries (Majumder et al. 2013). Zayneb (2015) discovered that superoxide dismutase, ascorbate peroxidase and catalase increased following exposure to excessive concentrations of Cd in Trigonella foenum-graecum (Zayneb et al. 2015).

Manganese is an essential trace element for plants. Nevertheless, plants exposed to increased Mn concentrations often suffer from Mn poisoning. Plants have developed various mechanisms, including compartmentalization, chelation, avoidance and exclusion, antioxidation, and ion interaction, to overcome Mn 
toxicity (Fernando et al. 2015). The exudation of organic acid mainly contributes to Mn detoxification, both internally and externally. Phytolacca acinosa may enhance its tissues tolerance to Mn by the exudation and transportation of organic acid following lower Mn treatments (Xue et al. 2011). Absorption bands of Phytolacca americana differ greatly in carbohydrates and proteins, largely because of the exudation and transportation of organic substances (Ren et al. 2007). $\mathrm{Mn}^{2+}$ release from soils was critical to elucidate the formation of Mn oxides and to assess the biotoxicity of excess $\mathrm{Mn}^{2+}$ to plants in an acid soil. The ability of organic acids to promote $\mathrm{Mn}^{2+}$ followed the order: citric acid $>$ pyritic acid $>$ tartaric acid $>$ malic acid $>$ lactic acid (Yang et al. 2011). The conversion of $\mathrm{Mn}^{2+}$ to a metabolically inactive compound by the Mn-oxalate complex, was a key detoxification mechanism (Dou et al. 2009); Mn can be sequestered into a large, metabolically inert intracellular compartment, and is one of the main mechanisms of Mn tolerance and accumulation (Xu et al. 2015).

P. perfoliatum is a Mn tolerant plant found in manganese wasteland tailings in Southern China. It can tolerate Mn concentrations of approximately $41400 \mathrm{mg} \cdot \mathrm{Kg}^{-1}$. In this paper P. perfoliatum was grown hydroponically in order to investigate if its chemical composition and ultrastructure were affected following exposure to varying Mn concentrations up to $10000 \mu \mathrm{mol} \cdot \mathrm{L}^{-1}$. We also attempt to understand the plants response mechanisms for reducing elevated Mn concentrations in its tissues.

\section{Materials and methods}

Hydroponics culture

Seeds of $P$. perfoliatum collected from wasteland tailings in Southern China were spread on sand-filled pots. Following germination ( 14 days), plants of the same size were selected and their roots thoroughly washed. Hoagland's nutrient solution (Xue et al. 2004) was used as the culture, which included $2.5 \mathrm{mM} \mathrm{Ca}\left(\mathrm{NO}_{3}\right)_{2}, 1 \mathrm{mM}$ $\mathrm{MgSO}_{4}, 0.5 \mathrm{mM} \mathrm{KCl}, 0.5 \mathrm{mM}\left(\mathrm{NH}_{4}\right) \mathrm{H}_{2} \mathrm{PO}_{4}, 2 \times 10^{-4} \mathrm{mM} \mathrm{CuSO}_{4}, 1 \times 10^{-3} \mathrm{mM} \mathrm{ZnSO}_{4}, 0.1 \mathrm{mM}$ EDTA Fe Na, $2 \times 10^{-2}$ $\mathrm{mM} \mathrm{H}_{3} \mathrm{BO}_{3}, 5 \times 10^{-6} \mathrm{mM}\left(\mathrm{NH}_{4}\right)_{6} \mathrm{Mo}_{7} \mathrm{O}_{24}, 1 \times 10^{-3} \mathrm{mM} \mathrm{MnSO}_{4}$. After a 7-day culture in 1/4 Hoagland's nutrient solution and an 8-day culture in 1/2 Hoagland's nutrient solution, plants were grown on in different Mn concentrations $\left(5,500,1000,2000,5000,10000 \mu \mathrm{mol} \cdot \mathrm{L}^{-1}\right)$, added as $\mathrm{MnCl}_{2}(\mathrm{AR})$. Each treatment was replicated 
three times. The process of collection and pretreatment of P. perfoliatum followed the standard procedure of Wang et al. (2016).

Plants, using pattern of solution culture (Full strength of Hoagland nutrient solution, , which included $2.5 \mathrm{mM}$ $\mathrm{Ca}\left(\mathrm{NO}_{3}\right)_{2}, 1 \mathrm{mM} \mathrm{MgSO}{ }_{4}, 0.5 \mathrm{mM} \mathrm{KCl}, 0.5 \mathrm{mM}\left(\mathrm{NH}_{4}\right) \mathrm{H}_{2} \mathrm{PO}_{4}, 2 \times 10^{-4} \mathrm{mM} \mathrm{CuSO}_{4}, 1 \times 10^{-3} \mathrm{mM} \mathrm{ZnSO}_{4}, 0.1 \mathrm{mM}$ EDTA Fe Na, $\left.2 \times 10^{-2} \mathrm{mM} \mathrm{H} 3 \mathrm{BO} 3,5 \times 10^{-6} \mathrm{mM}(\mathrm{NH} 4)_{6} \mathrm{Mo}_{7} \mathrm{O}_{24}, 1 \times 10-3 \mathrm{mM} \mathrm{MnSO}_{4}\right)$,

Mn content analysis

Electricity plate digestion was used with ICP-OES in the determination of manganese in subsamples of dried plant tissue (c. $0.1 \mathrm{~g})$. The experiment was repeated three times. The acid medium was $20 \mathrm{~mL}$ of aqua regia $(\mathrm{HCl}$ (AR, mass fraction=36-38\%): $\mathrm{HNO}_{3}\left(\mathrm{AR}\right.$, mass fraction=65\%) =1:3) and $2 \mathrm{~mL}$ of $\mathrm{HClO}_{4}(\mathrm{AR}$, mass fraction=70$72 \%$ ). Sample scouring time was 30s replicated three times. The wavelength of manganese was $2576 \mathrm{~nm}$.

FTIR analysis

The spectral information of various tissues and organs were investigated using Fourier Transform Infrared (FTIR) spectroscopy in the mid-IR range with a Nicolet IS10 infrared spectrometer. The characteristic wavelength was 4000 to $400 \mathrm{~cm}^{-1}$ with a resolution of $1 \mathrm{~cm}^{-1}$. Plant samples were finely blended with $\mathrm{KBr}(0.5 / 50 \mathrm{mg})$ using an agate mortar.

Cellular ultrastructure analysis

Subsamples of fresh plant tissue were cut into approximately 1-2 mm pieces with a scalpel and subsequently subjected to fixation and embedding protocols. Pretreatment of samples followed the procedure of Xue et al. (2016b). Specimens were sliced into ultrathin sections ( $80 \mathrm{~nm}$ slices), and the specific ultrastructures were characterized under a transmission electron microscope (JEOL TEM-1230EX). 
EDS analysis

Serial ultrathin sections (120 nm slices) of plant tissue were photographed for their electron cloud density distribution, followed by $\mathrm{X}$ - ray spectrum analysis with an EDAX-PHOENIX energy spectrum analyzer.

The working condition of the energy spectrum analyzer was as follows: acceleration voltage $80 \mathrm{kV}$, spot size 80 nm diameter, sample table dip $35^{\circ}$, CPS 1500 , test time 100 s.

\section{Statistical analysis}

All analyses were performed in quintuplicate. The data were statistically analyzed with Microsoft Excel 2016, SPSS version 22.0 and Origin 9.1.

\section{Results and discussion}

\section{Effect of Mn concentration on biomass of $P$. perfoliatum}

The total biomass of $P$. perfoliatum varied inversely with $\mathrm{Mn}$ concentration (Table 1). With elevated concentrations of Mn, biomass of $P$. perfoliatum significantly showed an overall reduction, but a slight increase was found at $2000 \mu \mathrm{mol} \cdot \mathrm{L}^{-1} \mathrm{Mn}$. In comparison to controls, fresh leaf biomass from $10000 \mu \mathrm{mol} \cdot \mathrm{L}^{-1} \mathrm{Mn}$ decreased by $60 \%$, and fresh root biomass decreased by $83.33 \%$. Plant growth was not affected at low concentrations, but differences were revealed at high concentrations such as slow growth and a significant reduction in biomass; the plants life cycle was nevertheless still completed. Furthermore, the ratio of leaf to root fresh biomass was related to Mn treatment.

Mn uptake and accumulation characteristics

Manganese translocation was found to be in the order: leaves> roots>stems (Table 2). Manganese content in $P$. perfoliatum tissues increased with increasing Mn concentration. In leaves, $\mathrm{Mn}$ reached $13138 \mathrm{mg} \cdot \mathrm{kg}^{-1}$ when grown in $500 \mu \mathrm{mol} \cdot \mathrm{L}^{-1} \mathrm{Mn}$. At $10000 \mu \mathrm{mol} \cdot \mathrm{L}^{-1}, \mathrm{Mn}$ content in stems and leaves reached its maximum, 16077 and $41400 \mathrm{mg} \cdot \mathrm{kg}^{-1}$, respectively. Manganese was an essential trace element for plants in the range of 20-500 $\mathrm{mg} \cdot \mathrm{kg}^{-1}$, 
133

134

135

136

137

138

139

140

141

142

143

144

145

146

147

148

149

150

151

152

153

154

155

156

157

158

but plants exposed to over $1500 \mathrm{mg} \cdot \mathrm{kg}^{-1} \mathrm{Mn}$ often suffer from Mn toxicity (Xue et al. 2010). P. perfoliatum showed stronger uptake and enrichment at low Mn concentrations as well as at high levels.

Translocation factor (hereafter referred to as TF) reflects the transportation and distribution of metals in plants from below to above ground. Manganese mainly accumulates in the leaves, which therefore increases its transportation. Plants can chelate Mn, which is then accumulated in the leaves and stems and is one of the important mechanisms by which its toxicity is reduced (Fernando et al. 2013). However, the TF between leaves and roots reached a maximum at $2000 \mu \mathrm{mol} \cdot \mathrm{L}^{-1} \mathrm{Mn}$. A possible reason for this may be chelation and the results support P. perfoliatum as a Mn tolerant plant.

Effect of Mn treatments on the chemical composition of $P$. perfoliatum

There was no distinguishing peak displacement, and shoulder peak varied little. Changes of absorbance were not obvious at Mn concentrations below $2000 \mu \mathrm{mol} \cdot \mathrm{L}^{-1}$, which shows that the exudation and transportation were little influenced during lower Mn treatments. Above $2000 \mu \mathrm{mol} \cdot \mathrm{L}^{-1} \mathrm{Mn}$, absorbance slightly increased but then decreased (Figure 1). This suggested that low concentrations of Mn stimulated the plants to produce organic acids and other exudates to overcome Mn toxicity, but high concentrations affected physiological process in cells.

The stretching vibration peak of $3420 \mathrm{~cm}^{-1}$ (free hydroxyl) is mainly reflected in root carbohydrate (cellulose, hemicelluloses, and polysaccharides) (Ren et al. 2008). The band height initially declined but then increased (Figure 1), probably because a large number of hydroxyls from root epidermal cell walls reacted with Mn thereby forming stable compounds. However, elevated exogenous Mn treatments appeared to damage this mechanism. Carboxylic acid O-H and methyl stretching vibration peaks overlapped near $2920 \mathrm{~cm}^{-1}$, mainly as a result of vitamins, membrane and cell wall components. With elevated concentrations of $\mathrm{Mn}$, the band height first decreased then increased. It may be that the production and transportation of organic compounds were associated with $\mathrm{Mn}$ treatments. Also, organic acids released from root cells chelated excessive $\mathrm{Mn}^{2+}$. The peak in $1380 \mathrm{~cm}^{-1}$ is produced by the $\mathrm{C}=\mathrm{O}$ stretching mode of carbonyl compounds in aliphatic ketones. Band height first decreased then increased (Figure 1). These results indicated that elevated exogenous Mn treatments increased soil cation 
exchange capacity by demethylation of pectin in cell walls, which may increase the tolerance to Mn toxicity. The

stretching vibration peak of $1060 \mathrm{~cm}^{-1}$ is mainly reflected in alcohol and ether-based ester or phenol group C-O bond. With elevated concentrations of Mn, the absorption peak first decreased then increased. The products of membrane lipid peroxidation accumulated in roots played the leading role in peak variation at Mn concentrations below $2000 \mu \mathrm{mol} \cdot \mathrm{L}^{-1}$, but excess $\mathrm{Mn}^{2+}$ damaged the process.

There was no distinguishing peak displacement, and shoulder peak varied little in stems of $P$. perfoliatum (Figure 2). With elevated Mn $\left(5-500 \mu \mathrm{mol} \cdot \mathrm{L}^{-1}\right)$, absorbance did not alter. Above $500 \mu \mathrm{mol} \cdot \mathrm{L}^{-1} \mathrm{Mn}$, absorbance increased slightly then decreased, which appears to show that $\mathrm{Mn}^{2+}$ promoted carbohydrate production. The peak near $1735 \mathrm{~cm}^{-1}$ is a methyl absorption band (membrane and cell wall) found in oil containing compounds. With increasing Mn concentration, the absorption peak initially decreased then increased, and the peak reached a maximum at $1000 \mu \mathrm{mol} \cdot \mathrm{L}^{-1}$. Early lipid peroxidation thereby reducing lipid content and production of aliphatic ketone compounds containing a carbonyl group which gradually increased may explain the increase in peak. Above $1000 \mu \mathrm{mol} \cdot \mathrm{L}^{-1} \mathrm{Mn}$, absorbance decreased. Results showed that carbohydrate increased following low Mn exposure, and $P$. perfoliatum strengthened the tolerance by adjusting its osmotic potential, membrane lipid peroxidation was enhanced with lipid and carbohydrate production decreasing at high levels.

Absorption spectra (FTIR) in leaves revealed that the absorption peaks were forced to shift and shoulder peaks had shrunk (Figure 3). With elevated Mn (5-1000 $\left.\mu \mathrm{mol} \cdot \mathrm{L}^{-1}\right)$, absorbance increased dramatically, which indicated that lower $\mathrm{Mn}^{2+}$ had promoted the production and transportation of organic compounds. There was no significant change in absorbance from 2000 to $5000 \mu \mathrm{mol} \cdot \mathrm{L}^{-1}$. Above $5000 \mu \mathrm{mol} \cdot \mathrm{L}^{-1}$, absorbance decreased dramatically, indicating that excess $\mathrm{Mn}^{2+}$ clearly had an impact on the production and transportation of carbohydrates and other organic substances in leaves of $P$. perfoliatum.

\section{Effect of Mn treatments on the ultrastructure of P. perfoliatum}

P. perfoliatum was grown under glasshouse conditions in order to study its ultrastructure following supply of nutrient solutions supplemented with increasing Mn concentrations $\left(5,1000\right.$, and $\left.10000 \mu \mathrm{mol} \cdot \mathrm{L}^{-1}\right)$. Lower Mn concentrations with 5 and $1000 \mu \mathrm{mol} \cdot \mathrm{L}^{-1}$ had no breakage function to the ultrastructure of $P$. perfoliatum (Fig 4A, 
Fig5A, Fig 6A, Fig 4B, Fig5B and Fig 6B). However, with an increase in Mn concentration of up to 10000 $\mu \mathrm{mol} \cdot \mathrm{L}^{-1}$, visible damage was evident (Fig 4C, Fig 5C and Fig 6C), the quantity of mitochondria in root cells increased and the grana lamellae of leaf cell chloroplasts became disorganized (Fig 4C, 7C). While chloroplast structure and function had obvious damage under excess $\mathrm{Mn}^{2+}, P$. perfoliatum still survived, suggesting that $P$. perfoliatum has a higher tolerance to excessive Mn concentrations.

Generally, excess $\mathrm{Mn}^{2+}$ has direct cytotoxicity such as to inhibit the uptake and activity of $\mathrm{Ca}^{2+}, \mathrm{Fe}^{2+}$ and $\mathrm{Mg}^{2+}$ whilst inducing oxidative stress, leading to decreased chlorophyll and rubisco contents, damaged chloroplast ultrastructures, reduced photosynthetic rate, and even death. However, certain plant species have evolved in heavy metal contaminated soils which can tolerate excess $\mathrm{Mn}^{2+}$ especially in the plant shoot (Blamey et al. 2015). In the present study, lower Mn concentrations with 5 and $1000 \mu \mathrm{mol} \cdot \mathrm{L}^{-1}$ had no breakage function to the ultrastructure of $P$. perfoliatum, and the effects on photosynthesis were minimal as observed by FTIR and TEM. In roots, the exudation of organic acids mainly contributes to Mn detoxification (both internally and externally), uptake and transport. The storage of Mn in the root cell walls may keep the ion sequestered from the root cytoplasm. In leaves, Mn preferentially accumulated in leaf epidermal cells which may be an avoidance mechanism to prevent damage to photosynthetic cells; epidermal cells lack chloroplasts. The conversion of $\mathrm{Mn}^{2+}$ to a metabolically inactive compound by organic acid or phenolic compounds, such as the Mn-oxalate complex, is an important detoxification mechanisms (Deng et al. 2010). Further understanding of the molecular mechanisms of Mn tolerance in plants requires further investigation.

P. perfoliatum had a high Mn tolerance, and it may be a result of its detoxification storage form in its cells. The metal transporters involved in removing Mn from the cytosol or moving it to the vacuolar membrane, where Mn can be sequestered into a large and relatively metabolically inert intracellular compartment, play important roles in Mn uptake, transportation and accumulation at the whole plant level (Zhang et al. 2010). Manganese accumulated in the supernatant part, accounting for $74 \%-82 \%$ of the total $\mathrm{Mn}$ in the leaves (Xu et al. 2009). Compared with controls, black agglomerations were found in cells of $P$. perfoliatum after treatment with 1000 and $10000 \mu \mathrm{mol} \cdot \mathrm{L}^{-1} \mathrm{Mn}$ after 30 days; these became obvious at higher Mn concentrations (Fig 5C and Fig 7C). Black agglomerations were found in cells of Mn tolerant plants, indicating that they were possibly manganese 
oxides (Dou et al. 2009, Papadakis et al. 2007 and Xue et al. 2016b). This is consistent with our results in that black agglomerations appeared in the high Mn treatments but this still requires further research.

Acicular substances analysis in leaves of P. Perfoliatum

At $10000 \mu \mathrm{mol} \cdot \mathrm{L}^{-1}, \mathrm{Mn}$ content in leaves reached a maximum, $41404 \mathrm{mg} \cdot \mathrm{kg}^{-1}$ indicating that $P$. perfoliatum strongly accumulates Mn after either long or short-term treatments. To avoid metal toxicity, plants have evolved mechanisms including efflux of metal ions from cells and sequestration into internal cellular compartments (Kim et al. 2004). At a Mn concentration of $10000 \mu \mathrm{mol} \cdot \mathrm{L}^{-1}$, a novel acicular substance developed in leaf cells and intercellular spaces, possibly indicating a tolerance mechanism in P. perfoliatum.

Through energy spectrum analysis Mn concentrations in acicular crystals were significantly greater than in other locations (Figure 8) and it might be a result of the compartmentation of $\mathrm{Mn}$ in the cells, possibly indicating a tolerance mechanism in P. perfoliatum.

Overexposure to Mn appears to be the basis of a more active extracellular covalent POD bound to the cell wall, being involved in the lignification process (Blamey et al. 2015). Manganese toxicity was also observed with reactions with other elements including phosphorus, calcium and ferrum. (Esteban et al. 2013). Manganese accumulation in epidermal cells suggests that the root endodermis hinders transportation of Mn, protecting the normal physiological processes of cells (Dučićet al. 2012). Phosphate contents in acicular substances by EDS were $7.92 \%$ and $11.46 \%$. Phosphate may consume and precipitate Mn reducing its biological activity, but it should be stressed that although it is confirmed that phosphate may play a major role in heavy metal tolerance mechanisms and phytoremediation, the role of phosphate on manganese accumulation in $P$. perfoliatum still requires further research (Kochian et al. 2004; Hauck et al. 2003).

\section{Conclusions}

The growth of $P$. perfoliatum was not affected by low concentrations of Mn, whilst differences were revealed at high concentrations, such as slow growth and a significant reduction in biomass. Manganese 
distribution was as follows: leaves $>$ roots $>$ stems, with a translocation factor $>1$. Effects of Mn on the plants chemical composition revealed that $P$. perfoliatum reduces Mn stress through a number of mechanisms including cells, which might be through fixation and precipitation of Mn with phosphate.

\section{Acknowledgements}

246 Financial support from National Natural Science Foundation of China (No. 40771181 ) and Environmental 247 protection's special scientific research for Chinese public welfare industry (No. 201109056) is gratefully 248 acknowledged.

\section{References}

251 Baker AJM, Brooks RR (1989) Terrestrial higher plants which hyperaccumulate metallic elements, a review of their 252 distribution. Ecology and Phytochemistry. Biorecovery 1:81-126.

253 Blamey P, Hernandez-Soriano M, Cheng M, Tang C, Paterson D, Lombi E, Wang WH, Scheckel K, Kopittke PM (2015). 254 Synchrotron-based techniques shed light on mechanisms of plant sensitivity and tolerance to high manganese in the root 255 environment. Plant Physiol 169(3):2006-2020.

256 Chen Z, Wang YP, Jiang XL, Fu D, Xia D, Wang HT, Dong GW, Li QB (2017) Dual roles of AQDS as electron shuttles for 257 microbes and dissolved organic matter involved in arsenic and iron mobilization in the arsenic-rich sediment.

258 Sci Total Environ 574:1684-1694.

259 Dou CM, Fu XP, Chen XC, Shi JY, Chen YX (2009) Accumulation and detoxification of manganese in hyperaccumulator 260 Phytolacca americana. Plant Biol 11(5):664-670.

261 Deng H, Li MS, Chen YX, Luo YP, Yu FM (2010) A new discovered manganese hyperaccumulator - Polygonum pubescens 262 Blume. Fresen Environ Bull 19(1):94-99. 
Dučić T, Thieme J, Polle A (2012) Phosphorus compartmentalization on the cellular level of Douglas fir root as affected by Mn toxicity: a synchrotron-based FTIR approach. Spectroscopy 27(5-6):265-272.

Esteban E, Deza MJ, Zornoza P (2013) Kinetics of mercury uptake by oilseed rape and white lupin: influence of Mn and Cu. Acta Physiol Plant 35(35):2339-2344.

Fernando DR, Marshall AT, Forster PI, Hoebee SE, Siegele R (2013) Multiple metal accumulation within a manganesespecific genus. Am J Bot 100(4):690-700.

Fernando DR., Lynch JP (2015) Manganese phytotoxicity: new light on an old problem. Ann Bot 116(3):313-319

Hao XZ, Zhou DM, Wang YK, Shi FG, Jiang P (2011) Accumulation of Cu, Zn, Pb, and Cd in edible parts of four commonly grown crops in two contaminated soils. Int J Phytorem 13(3):289-301.

Hauck M, Paul A, Gross S, Raubuch M (2003) Manganese toxicity in epiphytic lichens:chlorophyll degradation and interaction with iron and phosphorus. Environ Exp Bot 49(2):181-191.

Keller C, Rizwan M, Davidian JC, Pokrovsky OS, Bovet N, Chaurand P, Meunier JD (2015) Effect of silicon on wheat seedlings ( Triticum turgidum L.) grown in hydroponics and exposed to 0 to $30 \mu \mathrm{m} \mathrm{Cu}$. Planta 241(4): 847-860.

Kim D, Gustin JL, Lahner B, Michael W, Baek D, Yun DJ (2004) The plant CDF family member TgMTP1 from the Ni/Zn hyperaccumulator Thlaspi goesingense, acts to enhance efflux of $\mathrm{Zn}$ at the plasma membrane when expressed in saccharomyces cerevisiae. Plant J 39(2):237-251.

Kochian LV, Hoekenga OA, Pineros MA (2004) How do crop plants tolerate acid soils?-Mechanisms of aluminum tolerance and phosphorous efficiency. Annu Rev Plant Biol 55(1):459-493.

Kong XF, Li M, Xue SG, Hartley W, Chen CR, Wu C, Li XF, Li YW (2017) Acid transformation of bauxite residue: conversion of its alkaline characteristics. J Hazard Mater DOI: 10.1016/j.jhazmat.2016.10.073

Kupper H, Jie ZF, Mcgrath SP (1999) Cellular compartmentation of zinc in leaves of the hyperaccumulator Thlaspi caerulescens. Plant Physiol 119(1):305-12.

Li M, Cheng XH, Guo HX (2013) Heavy metal removal by biomineralization of urease producing bacteria isolated from soil. Int Biodeterior Biodegrad 76(1):81-85.

Liu YN, Guo ZH, Xiao XY, Wang S, Jiang ZC, Zeng P (2017) Phytostabilisation potential of giant reed for metals contaminated soil modified with complex organic fertiliser and fly ash: A field experiment. Sci Total Environ 576:292-302. Majumder S, Mishra D, Ram SS, Jana NK, Santra S, Sudarshan M, Chakraborty A (2013) Physiological and chemical response of the lichen, Flavoparmelia caperata (L.) Hale, to the urban environment of Kolkata, India. Environ Sci and Pollution Res 20(5):3077-3085.

Miao L, Yan W, Zhong L, Xu W (2014) Effect of heavy metals (Cu, Pb, and As) on the ultrastructure of Sargassum pallidum in Daya bay, china. Environ Monit Assess 186(1):87-95. 
Papadakis IE, Giannakoula AIN, Bosabalidis AM, Moustakas M, Nastou A (2007) Mn-induced changes in leaf structure and chloroplast ultrastructure of Citrus volkameriana (L.) plants. J Plant Physiol 164(1):100-103.

Ren LM, Cheng ZF, Liu P, Li ZG (2008) Studies on the physiological response of Phytolacca Americana to manganese toxicity by FTIR spectroscopy. Spectrosc Spect Anal 28(3):582-585.

Wang J, Ye S, Xue SG, Hartley W, Wu H, Shi LZ (2016) Lead accumulation and physiological response of Mirabilis jalapa Linn. to lead stress. Int Biodeterior Biodegrad DOI: 10.1016/j.ibiod.2016.04.030

Weng XY, Zhao LL, Zheng CJ, Zhu JW (2013) Characteristics of the hyperaccumulator plant Phytolacca acinosa (Phytolaccaceae) in response to excess manganese. J Plant Nutr 36(9): 1355-1365.

Wu C, Zou Q, Xue SG, Pan WS, Yue X, Hartley W, Huang L, Mo JY (2016) Effect of silicate on arsenic fractionation in soils and its accumulation in rice plants. Chemosphere 165: 478-486.

Wu C, Huang L, Xue SG, Pan WS, Zou Q, Hartley W, Wong MH (2017). Oxic and anoxic conditions affect arsenic (As) accumulation and arsenite transporter expression in rice. Chemosphere, DOI: 10.1016/j.chemosphere.2016.10.114

Xu XH, Shi JY, Chen XC, Chen YX, Hu TD (2009) Chemical forms of manganese in the leaves of manganese hyperaccumulator Phytolacca acinosa Roxb. (Phytolaccaceae). Plant Soil 38(1-2):197-204.

Xu XH, Yang JJ, Zhao XY, Zhang XS, Li RY (2015) Molecular binding mechanisms of manganese to the root cell wall of Phytolacca americana L. using multiple spectroscopic techniques. J Hazard Mater 296:185-191.

Xue SG, Chen YX, Reeves RD, Baker AJM, Lin Q, Fernando DR (2004) Manganese uptake and accumulation by the hyperaccumulator plant Phytolacca acinosa Roxb. (Phytolaccaceae). Environ Pollut 131(3):393-399.

Xue SG, Zhu F, Kong XF, Wu C, Huang L, Huang N, Hartley W (2016a) A review of the characterization and revegetation of bauxite residues (Red mud). Environ Sci and Pollution Res 23(2):1120-1132.

Xue SG, Zhu F, Wu C, Lei J, William Hartley, Pan WS (2016b) Effects of manganese on the microstructures of Chenopodium ambrosioides L., a manganese tolerant plant. Int J Phytoremed 18(7):710-719.

Yang J, Zhong LY, Guo RF (2011) Release of Mn( 30(7):1348-1353.

Zayneb C, Bassem K, Zeineb K, Grubb CD, Noureddine D, Hafedh M, Amine E (2015) Physiological responses of fenugreek seedlings and plants treated with cadmium. Environ Sci and Pollution Res 22(14):10679-10689.

Zhang F, Wan XQ, Zhai J (2014) Effects of nitrogen supplement on chlorophyll synthesis and chloroplast ultrastructure of poplar plants under cadmium stress. J Nucl Agric Sci 28(3):485-491. 